\title{
Badania laboratoryjne oddziaływania gazów kwaśnych na skałę zbiornikową w procesach sekwestracji $\mathrm{CO}_{2}$
}

\begin{abstract}
Stopień oddziaływania dwutlenku węgla na skały zbiornikowe jest bardzo ważnym elementem przy planowaniu procesu sekwestracji. W celu oceny wpływu $\mathrm{CO}_{2}$ na skały zbiornikowe zaprojektowano i wykonano specjalistyczne stanowisko badawcze umożliwiające poddanie rzeczywistych próbek skał zbiornikowych oddziaływaniu $\mathrm{CO}_{2}$ w warunkach dynamicznych. Eksperymenty wykonano dla dwóch piaskowców (piaskowiec węglowiecki, czerwony spągowiec) oraz dolomitu głównego. Dla każdej próbki (zarówno przed, jak i po eksperymencie) wykonane zostały badania podstawowych parametrów petrofizycznych, skład mineralogiczny oraz mikrotomografia rentgenowska. Na koniec dokonano analizy porównawczej otrzymanych wyników i tym samym określono wpływ oddziaływania gazów kwaśnych na badane skały.
\end{abstract}

Słowa kluczowe: sekwestracja, długotrwałe oddziaływanie $\mathrm{CO}_{2}$, rozpuszczalność $\mathrm{CO}_{2}$ w solance.

\section{Laboratory studies on the impact of acid gas reservoir rock in the process of $\mathrm{CO}_{2}$ sequestration}

Interaction of carbon dioxide $\left(\mathrm{CO}_{2}\right)$ on the reservoir rock is a very important element in sequestration planning. Therefore, in order to assess the impact of $\mathrm{CO}_{2}$ on the reservoir rock, a specialized test stand was designed and manufactured. It allowed the submission of actual samples of reservoir rock under the influence of $\mathrm{CO}_{2}$ in dynamic conditions. Experiments were done for two sandstone and one dolomite. For each sample (both before and after the experiment) were performed tests of the basic petrophysical parameters, mineralogical composition and x-ray microtomography. Finally a comparative analysis of the results was carried out, thereby the effect of the impact of acid gases on the studied rocks was specified.

Key words: sequestration, long-term $\mathrm{CO}_{2}$ experiments, $\mathrm{CO}_{2}$ brine interaction, solubility of $\mathrm{CO}_{2}$ in brine.

\section{Wstęp}

Zatłaczany do podziemnych struktur dwutlenek węgla oddziałuje na skałę zbiornikową i występujące w niej płyny złożowe. $\mathrm{CO}_{2}$ ulega rozpuszczeniu w płynie złożowym, a następnie reaguje z minerałami zawartymi w matrycy skalnej. Opisywane zjawisko ma znaczenie szczególnie w przypadku zatłaczania gazów kwaśnych do podziemnych poziomów solankowych, jak i struktur naftowych. Brak odpowiednich badań i niewiedza mogą doprowadzić do przykrych w skutkach i nieodwracalnych zjawisk. Dlatego w celu oceny wpływu $\mathrm{CO}_{2}$ na skały zbiornikowe zaprojektowano i wykonano specjalistyczne stanowisko badawcze umożliwiające poddanie rzeczywistych próbek skał zbiornikowych oddziaływaniu $\mathrm{CO}_{2}$ rozpuszczonego w solance $\mathrm{w}$ warunkach ciśnienia i temperatury złożowej. Do tego celu wykorzystano materiały skalne pochodzące $\mathrm{z}$ terenów reprezentujących największe struktury naftowe w Polsce, tj: piaskowiec węglowiecki z przedgórza Karpat, czerwony spągowiec z obszaru niecki poznańskiej, a także dolomit główny.

W perspektywie stale rosnącej emisji $\mathrm{CO}_{2}$ do atmosfery coraz bardziej realnym staje się sekwestracja $\mathrm{CO}_{2}$ do podziemnych struktur geologicznych. Zatłaczany dwutlenek węgla w pierwszej kolejności rozpuszcza się w płynie złożowym, 
a następnie oddziałuje na skałę złożową. Rozpoznanie zachodzących zjawisk w skałach zbiornikowych jest bardzo istotne dla podziemnego zatłaczania/składowania dwutlenku węgla.

\section{Reakcje chemiczne dwutlenku węgla w procesach sekwestracji}

Oddziaływanie $\mathrm{CO}_{2}$ dotyczy m.in.: kinetyki rozpuszczania się $\mathrm{CO}_{2}$, mineralnego wiązania, pojawiania się nowych faz mineralnych, przemieszczania się $\mathrm{CO}_{2} \mathrm{w}$ złożu. Znajomość tych zjawisk umożliwia optymalizację zatłaczania gazu, a niewiedza może doprowadzić do niepowodzenia procesu podziemnego składowania dwutlenku węgla [8].

W przypadku składowania $\mathrm{CO}_{2}$ pod ciśnieniem przekraczającym ciśnienie krytyczne 7,38 MPa i w temperaturze górotworu ponad $31,1^{\circ} \mathrm{C}$ przechodzi on w stan nadkrytyczny, który powoduje wzrost jego gęstości, a tym samym zwiększa ilość zmagazynowaną w jednostce objętości. Ważnym czynnikiem efektywności składowania $\mathrm{CO}_{2}$ jest zapewnienie warunków nadkrytycznych: głębokość składowania powinna być większa niż $800 \mathrm{~m}$.

Zatłaczany $\mathrm{CO}_{2} \mathrm{w}$ pierwszej kolejności ulega rozpuszczeniu w płynach złożowych (najczęściej solance). Proces ten prowadzi do powstania roztworu kwasu węglowego, a tym samym powoduje zmianę $\mathrm{pH}$. Poniżej przedstawiono typowy przebieg reakcji chemicznych zachodzących podczas zatłaczania $\mathrm{CO}_{2}$ [7]

$\mathrm{CO}_{2}+\mathrm{H}_{2} \mathrm{O} \Leftrightarrow \mathrm{H}_{2} \mathrm{CO}_{3}$ - rozpuszczanie i powstawanie kwasu węglowego,

$\mathrm{H}_{2} \mathrm{CO}_{3} \mathrm{H}^{+}+\mathrm{HCO}_{3}^{-}$- dysocjacja kwasu węglowego, $\mathrm{CO}_{2}+\mathrm{CaCO}_{3}+\mathrm{H}_{2} \mathrm{O} \Leftrightarrow \mathrm{Ca}_{2}^{+}+2 \mathrm{HCO}_{3}^{-}-$reakcja towarzysząca dysocjacji kwasu węglowego.

W przypadku obecności jonów metali w solance dodatkowo mają miejsce reakcje jonowe [2]. W tablicy 1 zestawiono minerały mogące brać udział w reakcjach w procesie sekwestracji $\mathrm{CO}_{2}$.

Wymienione poniżej reakcje chemiczne mogą mieć znaczący wpływ na procesy sekwestracji $\mathrm{CO}_{2}$.

$$
\begin{aligned}
& \mathrm{Ca}^{2+}+\mathrm{HCO}_{3}^{-} \Leftrightarrow \mathrm{CaCO}_{3} \downarrow+\mathrm{H}^{+} \\
& \mathrm{Mg}^{2+}+\mathrm{HCO}_{3}^{-} \Leftrightarrow \mathrm{MgCO}_{3} \downarrow+\mathrm{H}^{+} \\
& \mathrm{Fe}^{2+}+\mathrm{HCO}_{3}^{-} \Leftrightarrow \mathrm{FeCO}_{3} \downarrow+\mathrm{H}^{+}
\end{aligned}
$$

Minerały z grupy siarczków i węglanów, spotykane w skałach osadowych będących również skałami zbiornikowymi, ulegają bardzo szybko rozpuszczeniu. Jest to obserwowane głównie w pobliżu odwiertów zatłaczających. Proces ten odnotowano na jedynej tego typu instalacji w Polsce.
Od stycznia 1996 roku do dziś działa pierwsza w Europie instalacja przemysłowego składowania gazów kwaśnych wydzielanych podczas eksploatacji złoża gazu ziemnego $[5,6]$. $\mathrm{W}$ instalacji tej zatłaczany do górotworu gaz pochodzi z aminowego oczyszczania gazu ziemnego. Proces w Borzęcinie polega na wydobyciu gazu i odseparowaniu od niego składników kwaśnych $\left(\mathrm{CO}_{2} \mathrm{i} \mathrm{H}_{2} \mathrm{~S}\right)$. Oddzielone gazy są powrotnie zatłaczane do strefy zawodnionej, podścielającej złoże gazu ziemnego. Instalacja z powodzeniem działa do dnia dzisiejszego i stała się rzeczywistym poligonem badań i doświadczeń. Analizując przebieg zmian parametrów złożowych w strefie przyodwiertowej (rysunek 1), stwierdzono, że po trzech miesiącach i iniekcji około 18 tys. $\mathrm{Nm}^{3}$ gazu nastąpił spadek ciśnienia zatłaczania z początkowego 10,4 MPa przez 8,4 do 6,6 MPa. Można przypuszczać, że - ze względu na dużą koncentrację $\mathrm{CO}_{2}$ w zatłaczanych gazach - powstający kwas węglowy rozpuścił lepiszcze i częściowo matrycę skał złożowych, zmniejszając w efekcie opory przepływu zatłaczanego gazu $[4,5]$. Jest to potwierdzeniem szybkiego oddziaływania dwutlenku węgla na osadową skałę zbiornikową.

Kolejnym ważnym czynnikiem w sekwestracji $\mathrm{CO}_{2}$ są właściwości solanki. Mineralizacja solanki ma zdecydowany wpływ na zdolność rozpuszczania się w niej gazu. Wyraźnie dowodzą tego uzyskane wyniki badań przeprowadzonych w INiG - PIB, dotyczące rozpuszczalności użytych gazów węglowodorowych i $\mathrm{CO}_{2}$ w solankach i w wodzie destylo-

\begin{tabular}{|c|c|}
\hline Nazwa Minerału & Wzór sumaryczny \\
\hline Plagiokłaz & $\mathrm{Ca}\left[\mathrm{Al}_{2} \mathrm{Si}_{2} \mathrm{O}_{8}\right]$ \\
\hline Oliwin & $\mathrm{Mg}_{2} \mathrm{SiO}_{4}-\mathrm{Fe}_{2} \mathrm{SiO}_{4}$ \\
\hline Piroksen (enstatyt) & $(\mathrm{Mg}, \mathrm{Fe})_{2} \mathrm{Si}_{2} \mathrm{O}_{6}$ \\
\hline Piroksen (augit) & $(\mathrm{Ca}, \mathrm{Mg}, \mathrm{Fe}(\mathrm{II}), \mathrm{Al})_{2}(\mathrm{Si}, \mathrm{Al})_{2} \mathrm{O}_{6}$ \\
\hline Hornblenda & $\mathrm{Ca}_{2} \mathrm{Na}_{0-1}(\mathrm{Mg}, \mathrm{Fe}(\mathrm{II}))_{3-5}(\mathrm{Al}, \mathrm{Fe}(\mathrm{III}))_{2-0}\left[\mathrm{Si}_{6-8} \mathrm{Al}_{2-0} \mathrm{O}_{22}\right](\mathrm{O}, \mathrm{OH})_{2}$ \\
\hline Węglany - amfibole-termolit & $\mathrm{Ca}_{2} \mathrm{Na}_{0-1}(\mathrm{Mg}, \mathrm{Fe}(\mathrm{II}))_{3-5}(\mathrm{Al}, \mathrm{Fe}(\mathrm{III}))_{2-0}\left[\mathrm{Si}_{6-8} \mathrm{Al}_{2-0} \mathrm{O}_{22}\right](\mathrm{O}, \mathrm{OH})_{2}$ \\
\hline Miki-flogopit & $\mathrm{K}_{2}(\mathrm{Mg}, \mathrm{Fe}(\mathrm{II}))_{6}\left[\mathrm{Si}_{6} \mathrm{Al}_{; 2} \mathrm{O}_{20}\right](\mathrm{OH})_{4}$ \\
\hline Miki-biotyt & $\mathrm{K}_{2}(\mathrm{Mg}, \mathrm{Fe}(\mathrm{II}))_{6-4}(\mathrm{Fe}(\mathrm{III}), \mathrm{Al})_{0-2}\left[\mathrm{Si}_{6-5} \mathrm{Al}_{; 2-3} \mathrm{O}_{20}\right](\mathrm{OH})_{4-2}$ \\
\hline Serpentyn & $\mathrm{Mg}_{6} \mathrm{Si}_{4} \mathrm{O}_{10}(\mathrm{OH})_{8}$ \\
\hline Chloryt & $(\mathrm{Mg}, \mathrm{Al}, \mathrm{Fe}(\mathrm{II}))_{12}\left[(\mathrm{Si}, \mathrm{Al})_{8} \mathrm{O}_{20}\right](\mathrm{OH})_{16}$ \\
\hline Illit & $\mathrm{K}_{1-1.5}(\mathrm{Fe}(\mathrm{III}), \mathrm{Al}, \mathrm{Fe}(\mathrm{II}), \mathrm{Mg})_{4.0}\left[\mathrm{Si}_{7-6.5} \mathrm{Al}_{; 1-1.5} \mathrm{O}_{20}\right](\mathrm{OH})_{4}$ \\
\hline Smektyt & $(1 / 2 \mathrm{Ca}, \mathrm{Na})_{0.7}(\mathrm{Al}, \mathrm{Mg}, \mathrm{Fe})_{4}(\mathrm{Si}, \mathrm{Al})_{8} \mathrm{O}_{20}(\mathrm{OH})_{4} \cdot \mathrm{nH}_{2} \mathrm{O}$ \\
\hline
\end{tabular}
wanej. Solanki o niższym stopniu mineralizacji, a co za tym
Tablica 1. Minerały skałotwórcze mogące brać udział w reakcji z $\mathrm{CO}_{2}[10]$ 


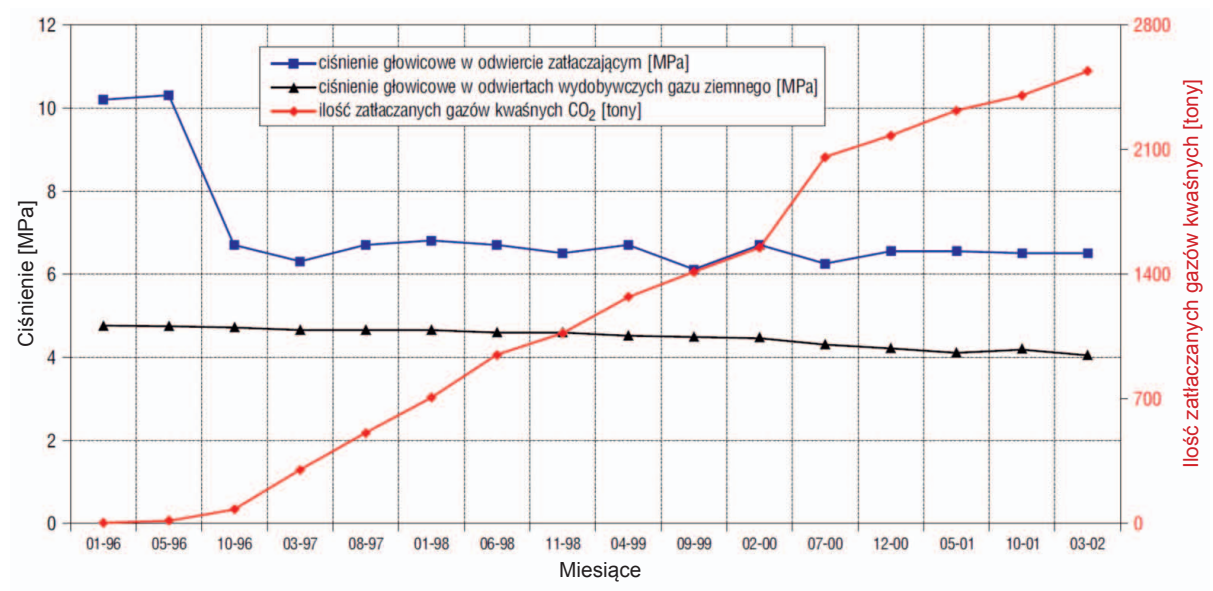

Rys. 1. Parametry procesu powrotnego zatłaczania gazów kwaśnych do zawodnionych stref złożowych Kopalni Gazu Ziemnego Borzęcin w latach 1996-2002 [5] w porównaniu z minerałami glinokrzemianowymi.

Długoterminowe zatłaczanie $\mathrm{CO}_{2}$ do górotworu może mieć pozytywny efekt w postaci strącania węglanów, a tym samym polepszenia bezpieczeństwa składowania. Natomiast rozpuszczanie skaleni silnie związane jest z pH solanki nasyconej $\mathrm{CO}_{2} \mathrm{w}$ warunkach złożowych $[1,3]$.

Minerały ilaste mogą reagować tylko z $\mathrm{CO}_{2}$ w fazie nadkrytycznej i tylko w przypadku długoterminowego kontaktu (czas eksperymentu - $365 \mathrm{dni}$ ). W trakcie badań krótkoterminowych idzie - o niższej gęstości, charakteryzują się większą zdolnością do rozpuszczania $\mathrm{CO}_{2}$. Lepsze rozpuszczanie gazu w wodzie zachodzi przy niższych temperaturach. Wraz ze wzrostem temperatury rozpuszczalność gazu spada, lecz powyżej $100^{\circ} \mathrm{C}$ zaczyna rosnąć. Porównanie rozpuszczalności gazów w wodzie destylowanej i solance stanowi cenny materiał naukowy i potwierdza fakt dużego wpływu mineralizacji na zdolność rozpuszczania się gazu w wodzie, w każdych warunkach ciśnienia i temperatury [9].

W pobliżu odwiertu zatłaczającego minerały węglanowe rozpuszczają się pod wpływem oddziaływania $\mathrm{CO}_{2}$. Na szybkość rozpuszczania mają wpływ ciśnienie, temperatura, mineralizacja, skład solanki i przede wszystkich czas oddziaływania na strefę przyodwiertową. W dalszej odległości od odwiertu rozpuszczone minerały mogą wytrącać się z solanki nasyconej $\mathrm{CO}_{2}$ na skutek zmian $\mathrm{pH}$, temperatury i ciśnienia. Tempo rozpuszczania skał węglanowych jest większe zachodzące zmiany bywają trudne do zaobserwowania [1].

Wielu autorów twierdzi, że następuje przekształcanie krzemionki, na skutek oddziaływania na nią $\mathrm{CO}_{2}$, w minerały węglanowe (karbonizację), czyli proces, w którym minerały zawierające wapń, magnez i potas przekształcają się w stabilne węglany. Nie zmienia to jednak faktu, że przeprowadzali oni swoje eksperymenty w warunkach statycznych, wykorzystując do tego celu komory ciśnieniowe, w których umieszczali badany materiał skalny, a następnie wtłaczali $\mathrm{CO}_{2}$ lub $\mathrm{CO}_{2}$ i solankę (najczęściej syntetyczną). Jedynie K. Zemke w 2009 roku zastosował solankę nasyconą nadkrytycznym $\mathrm{CO}_{2}$. Wykazał on przemiany w materiale skalnym minerałów z grupy biotytu, plagioklazu, skaleni alkaicznych oraz węglanów [11].

W niniejszym opracowaniu wykorzystana została specjalistyczna komora ciśnieniowa, która dzięki swej unikatowej konstrukcji umożliwiała przetłaczanie płynu (solanka nasycona nadkrytycznym $\mathrm{CO}_{2}$ ) oddziałującego na materiał skalny.

\section{Badania laboratoryjne}

Badania oddziaływania $\mathrm{CO}_{2}$ na skały zbiornikowe przeprowadzone zostały w warunkach laboratoryjnych. Analiza materiału skalnego odbywała się na specjalnie do tego celu skonstruowanym stanowisku badawczym (rysunek 2), umożliwiającym odtworzenie rzeczywistych warunków ciśnienia i temperatury złożowej. Kolejną bardzo ważną cechą wykorzystanej komory ciśnieniowej była możliwość cyklicznej wymiany solanki nasyconej $\mathrm{CO}_{2}$. Tak przeprowadzony eksperyment umożliwił odtworzenie warunków, jakim są poddawane skały w strefie przyodwiertowej.

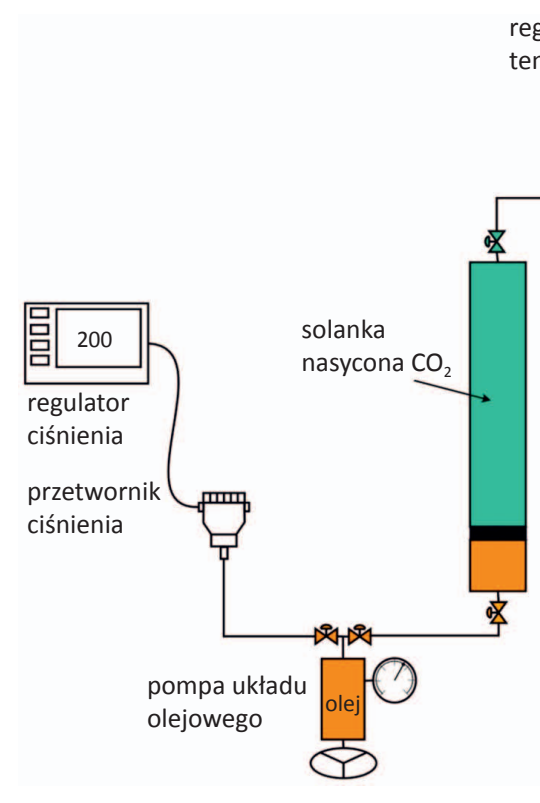


Próbki skalne poddano kompleksowym badaniom przed i po eksperymencie. Pozwoliły one określić:

- przepuszczalność,

- porowatość,

- skład mineralogiczny (zmiany w składzie),
- wizualizacje struktury porowej - mikrotomografia rentgenowska.

Przeprowadzenie tych badań - zarówno przed, jak i po eksperymencie - umożliwiło dokonanie analizy porównawczej zmierzonych parametrów.

\section{Badania rozpuszczalności $\mathrm{CO}_{2}$ w solance złożowej pochodzącej z odwiertu Porażyn-2A}

Pomiary rozpuszczalności dwutlenku węgla w wodzie złożowej Porażyn-2A prowadzono z wykorzystaniem nowoczesnej bezrtęciowej aparatury PVT do badań właściwości fazowych płynów złożowych.

W prezentowanych badaniach eksperymentalnych określono rozpuszczalność $\mathrm{CO}_{2} \mathrm{w}$ solance złożowej. Ponadto wyznaczono izotermy rozpuszczalności dwutlenku węgla $\mathrm{w}$ wodzie złożowej. Badania wykonano w dwóch temperaturach, tj.: $30 \mathrm{i} 100^{\circ} \mathrm{C}$. W tablicy 2 zestawiono główne parametry wody złożowej wykorzystanej we wszystkich przeprowadzonych eksperymentach.

Tablica 2. Wyniki pomiarów i oznaczeń chemicznych wody złożowej Porażyn-2A

\begin{tabular}{|l|c|}
\hline \multicolumn{1}{|c|}{ Oznaczenie } & $\begin{array}{c}\text { Woda złożowa } \\
\text { Porażyn-2A }\end{array}$ \\
\hline Gęstość w $20^{\circ} \mathrm{C}\left[\mathrm{g} / \mathrm{cm}^{3}\right]$ & 1,132 \\
\hline Odczyn $\mathrm{pH}$ & 5,66 \\
\hline Sucha pozostałość $\left[\mathrm{g} / \mathrm{dm}^{3}\right]$ & 211,3 \\
\hline Chlorki $\left[\mathrm{g} / \mathrm{dm}^{3}\right]$ & 120,5 \\
\hline Siarczany $\left[\mathrm{mg} / \mathrm{dm}^{3}\right]$ & 218 \\
\hline Ca $\left[\mathrm{mg} / \mathrm{dm}^{3}\right]$ & 27850 \\
\hline $\mathrm{K}\left[\mathrm{mg} / \mathrm{dm}^{3}\right]$ & 1638 \\
\hline $\mathrm{Mg}\left[\mathrm{mg} / \mathrm{dm}^{3}\right]$ & 1036 \\
\hline $\mathrm{Na}\left[\mathrm{mg} / \mathrm{dm}^{3}\right]$ & 39220 \\
\hline
\end{tabular}

Zwiększona zdolność dwutlenku węgla do rozpuszczania się w wodzie pozwoliła na dokonanie pewnych dodatkowych pomiarów wolumetrycznych badanego płynu, dzięki czemu określono współczynniki objętościowe solanki nasyconej $\mathrm{CO}_{2} \mathrm{w}$ zadanych warunkach ciśnienia i temperatury.

Uzyskane zbiorcze wyniki badań rozpuszczalności zilustrowano na rysunkach 3 i 4. Najwyższe wartości rozpusz- czalności osiągnięto podczas kontaktowania $\mathrm{CO}_{2} \mathrm{z}$ wodą złożową Porażyn w temperaturze $30^{\circ} \mathrm{C}\left(R s_{\mathrm{CO}_{2}}=21,2 \mathrm{Nm}^{3} / \mathrm{m}^{3}\right)$. Zdolność $\mathrm{CO}_{2}$ do rozpuszczania się w temperaturze $100^{\circ} \mathrm{C}$ była niższa o około $13 \%\left(R s_{\mathrm{CO}_{2}}=18,5 \mathrm{Nm}^{3} / \mathrm{m}^{3}\right)$.

Można także stwierdzić, że w przebadanym zakresie ciśnień i temperatur lepsze rozpuszczanie gazu w solance zachodzi przy niższych temperaturach oraz wysokim ciśnieniu.

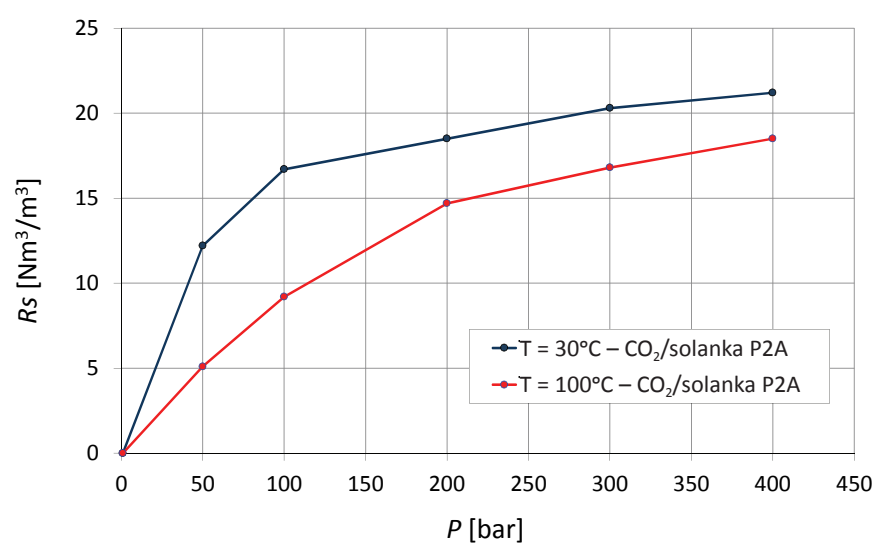

Rys. 3. Rozpuszczalność $\mathrm{CO}_{2}$ w wodzie złożowej Porażyn-2A [9]

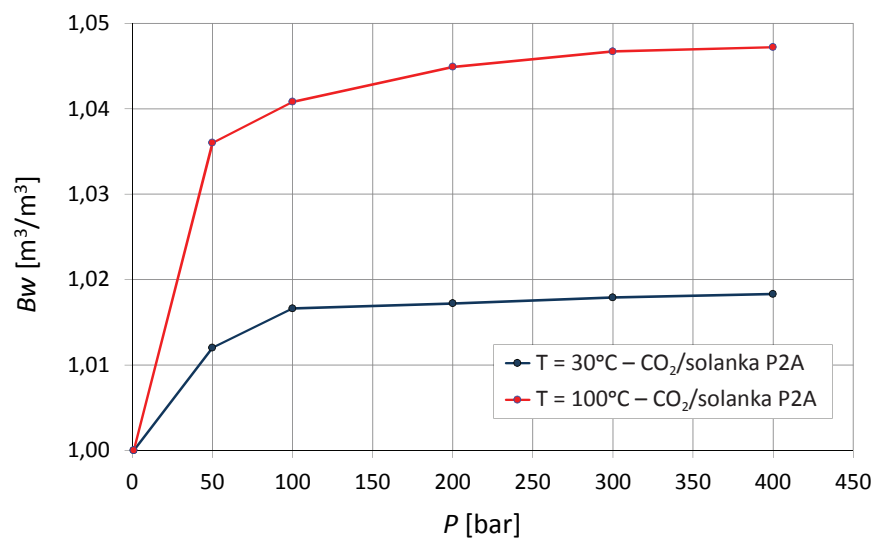

Rys. 4. Współczynnik objętościowy solanki Porażyn-2A nasycanej $\mathrm{CO}_{2}[9]$

\section{Badania laboratoryjne oddziaływania $\mathrm{CO}_{2}$ rozpuszczonego w solance Porażyn-2A na różne skały zbiornikowe}

Z materiału skalnego wycinano koronką (w płaszczyźnie poziomej) walce o średnicy 1". Długość pojedynczego kawałka rdzenia przygotowanego do badań wynosiła 50 $\div 65 \mathrm{~mm}$. Po wycięciu rdzenie były oczyszczane. W aparacie Soxhleta wielokrotnie przemywano je w zamkniętym procesie odparowania i skraplania substancji stanowiącej rozpuszczalnik. Oczyszczone rdzenie osuszano, pozostawiając w suszarce na okres kilku godzin w temperaturze $105^{\circ} \mathrm{C}$. 
Dopiero tak przygotowany materiał skalny poddawany był kolejnym badaniom.

W pierwszej kolejności odcięte zostały pięciomilimetrowe fragmenty każdego z rdzeni, a następnie określono ich skład mineralogiczny. Dla pozostałych fragmentów wykonane zostały pomiary przepuszczalności i porowatości. Ostatnim badaniem przed przystąpieniem do właściwego eksperymentu była mikrotomografia rentgenowska mająca na celu zobrazowanie struktury porowej badanych próbek.

Przeprowadzenie eksperymentu polegało na umieszczeniu próbki skalnej w komorze rdzeniowej. Następnie cały układ wypełniono solanką nasyconą $\mathrm{CO}_{2}$ (Pnas $=200$ bar). Dla bezpieczeństwa przed rozgazowaniem przez cały czas trwania eksperymentu w układzie utrzymywano stałe ciśnienie - około 20 bar powyżej ciśnienia nasycenia solanki. We wszystkich eksperymentach użyta została solanka pochodząca z odwiertu Porażyn-2A.

\section{Eksperyment 1}

Do wykonania pierwszego eksperymentu wykorzystano rdzeń oznaczony numerem 2273 (materiał skalny reprezentujący piaskowiec węglowiecki), o dobrych wartościach przepuszczalności i porowatości. Rdzeń nasycono odpowiednio przygotowaną solanką pochodzącą z odwiertu Porażyn-2A $\left(\mathrm{P}_{\text {nasCO2 }}=200\right.$ bar $)$. W czasie 30-dniowego eksperymentu przez rdzeń przetłoczono $54 \mathrm{PV}$ (objętości porowej rdzenia) solanki nasyconej $\mathrm{CO}_{2}$, stale utrzymując ciśnienie 220 bar i temperaturę $30^{\circ} \mathrm{C}$. Wyniki badań próbki skalnej piaskowca węglowieckiego przedstawiono w tablicach 3, 4 i 5.

W przypadku piaskowca węglowieckiego wykazano nieznaczną zmianę w zawartości kwarcu, zmniejszenie ilości minerałów ilastych, miki i illitu (tablica 4). Zawartość skaleni potasowych uległa ponad dwukrotnemu zwiększeniu. Na uwagę zasługują niewykazane w składzie plagioklazy oraz anhydryt, których niewielkie ilości odnotowano przed eksperymentem.

Tablica 3. Wyniki badań petrofizycznych próbki piaskowca węglowieckiego

\begin{tabular}{|c|c|c|c|c|c|}
\hline & $\begin{array}{l}\text { Współczynnik } \\
\text { przepuszczalności }\end{array}$ & $\begin{array}{c}\text { Współczynnik } \\
\text { porowatości efektywnej }\end{array}$ & $\begin{array}{c}\text { Objętość } \\
\text { przestrzeni porowej }\end{array}$ & $\begin{array}{c}\text { Gęstość } \\
\text { szkieletowa skał }\end{array}$ & $\begin{array}{l}\text { Masa } \\
\text { rdzenia }\end{array}$ \\
\hline & {$[\mathrm{mD}]$} & {$[\%]$} & {$\left[\mathrm{cm}^{3}\right]$} & {$\left[\mathrm{g} / \mathrm{cm}^{3}\right]$} & {$[\mathrm{g}]$} \\
\hline 2273 przed eksperymentem & 26,91 & 12,16 & 3,710 & 2,641 & 73,120 \\
\hline 2273 po eksperymencie & 22,96 & 11,86 & 3,730 & 2,632 & 72,990 \\
\hline 2273 wartość zmian & $-3,95$ & $-0,30$ & 0,020 & $-0,010$ & $-0,130$ \\
\hline $\begin{array}{l}2273 \text { zmiana parametru } \\
\text { wyrażona w \% }\end{array}$ & 14,70 & 2,50 & 0,500 & 0,300 & 0,200 \\
\hline
\end{tabular}

Tablica 4. Zmiany zawartości minerałów dla próbki piaskowca węglowieckiego przed i po eksperymencie

\begin{tabular}{|c|c|c|c|c|c|c|}
\hline $\begin{array}{c}\text { Kwarc } \\
{[\%]}\end{array}$ & $\begin{array}{c}\text { Plagioklazy } \\
{[\%]}\end{array}$ & $\begin{array}{c}\text { Skaleń potasowy } \\
{[\%]}\end{array}$ & $\begin{array}{c}\text { Anhydryt } \\
{[\%]}\end{array}$ & $\begin{array}{c}\text { Miki + illit } \\
{[\%]}\end{array}$ & $\begin{array}{c}\text { Suma } \\
{[\%]}\end{array}$ & $\begin{array}{c}\text { Suma minerałów ilastych } \\
{[\%]}\end{array}$ \\
\hline \multicolumn{7}{|c|}{ Przed eksperymentem } \\
\hline 82,7 & 1,3 & 3,4 & 3,7 & 8,9 & 100,0 & 8,9 \\
\hline \multicolumn{7}{|c|}{ Po eksperymencie } \\
\hline 85,2 & 0,0 & 8,7 & 0,0 & 6,1 & 100,0 & 6,1 \\
\hline
\end{tabular}

Tablica 5. Wyniki mikrotomografii rentgenowskiej dla piaskowca węglowieckiego

\begin{tabular}{|c|c|c|}
\hline \multicolumn{2}{|c|}{ Piaskowiec węglowiecki } \\
\hline $\begin{array}{c}\text { Zmiana } \\
\text { porowatości }\end{array}$ & Przed & Po \\
\hline & $2,8 \%$ & $1,7 \%$ \\
\hline $\begin{array}{c}\text { Obrazy } \\
\text { struktury } \\
\text { porowej }\end{array}$ & & \\
& & \\
\end{tabular}

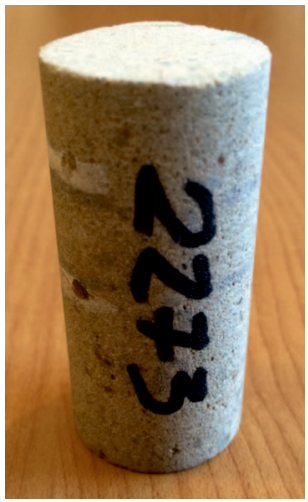

Rys. 5. Rdzeń piaskowca węglowieckiego przygotowany do badań 
Na powyższych wykresach przedstawiono obraz struktury porowej sklasyfikowanej według objętości wydzielonych podsystemów porów. Kolorystyka odpowiada następującym zakresom objętości: kolor żółty $1 \div 9$ wokseli, niebieski 10 $\div 99$ wokseli, czerwony 100 $\div 999$ wokseli, zielony $1000 \div 9999$ wokseli, biały $10000 \div 99999$ wokseli, fioletowy 100 000 $\div 400000$ wokseli, różowy - powyżej 400000 wokseli. Rozmiar woksela dla badanej próbki wynosił $15 \times 15 \times 15 \mu \mathrm{m}^{3}$.

\section{Eksperyment 2}

Do wykonania eksperymentu nr 2 wykorzystano rdzeń oznaczony symbolem CS2 (materiał skalny reprezentujący czerwony spągowiec) o niskich wartościach przepuszczalności i dobrej porowatości. Rdzeń nasycono tak jak poprzednio solanką pochodzącą z odwiertu Porażyn-2A.

W czasie 30-dniowego eksperymentu przez rdzeń przetłoczono $56 \mathrm{PV}$ (objętości porowej rdzenia) solanki nasyconej
$\mathrm{CO}_{2}$, stale utrzymując ciśnienie 220 bar i temperaturę $100^{\circ} \mathrm{C}$. Wyniki badań próbki skalnej czerwonego spągowca przedstawiono w tablicach 6,7 i 8 .

W badanej próbce rdzenia czerwonego spągowca wykazano niewielką zmianę w zawartości kwarcu, plagioklazu i dolomitu. Wzrosła zawartość anhydrytu i miki z illitem. Zmniejszyła się tylko ilość skaleni potasowych (tablica 7). Po eksperymencie nie wykazano obecności pirytu i chlorytu, których niewielkie ilości odnotowano przed eksperymentem.

Na powyższych wykresach przedstawiono obraz struktury porowej sklasyfikowanej według objętości wydzielonych podsystemów porów. Kolorystyka odpowiada następującym zakresom objętości: kolor żółty $1 \div 9$ wokseli, nie-

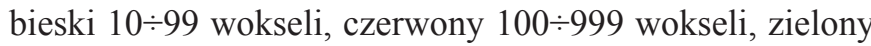
$1000 \div 9999$ wokseli, biały $10000 \div 99999$ wokseli, fioletowy 100 000 $\div 400000$ wokseli, różowy - powyżej 400000 wokseli. Rozmiar woksela dla badanej próbki wynosił $15 \times 15 \times 15 \mu \mathrm{m}^{3}$.

Tablica 6. Wyniki badań petrofizycznych próbki czerwonego spągowca

\begin{tabular}{|l|c|c|c|c|c|}
\cline { 2 - 6 } \multicolumn{1}{c|}{} & $\begin{array}{c}\text { Współczynnik } \\
\text { przepuszczalności }\end{array}$ & $\begin{array}{c}\text { Współczynnik } \\
\text { porowatości efektywnej }\end{array}$ & $\begin{array}{c}\text { Objętość } \\
\text { przestrzeni porowej }\end{array}$ & $\begin{array}{c}\text { Gęstość } \\
\text { szkieletowa skał }\end{array}$ & $\begin{array}{c}\text { Masa } \\
\text { rdzenia }\end{array}$ \\
\cline { 2 - 6 } & {$[\mathrm{mD}]$} & {$[\%]$} & 1,968 & 2,631 & 57,710 \\
\hline CS2 przed eksperymentem & 5,187 & 8,23 & 2,199 & 2,646 & 56,240 \\
\hline CS2 po eksperymencie & 1,620 & 9,38 & 0,230 & 0,020 & $-1,4700$ \\
\hline CS2 wartość zmian & $-3,570$ & 1,15 & 11,700 & 0,600 & $-2,500$ \\
\hline $\begin{array}{l}\text { CS2 zmiana parametru } \\
\text { wyrażona w \% }\end{array}$ & $-68,80$ & 14,00 & $\left.\mathrm{~cm}^{3}\right]$ & \\
\hline
\end{tabular}

Tablica 7. Zmiany zawartości minerałów dla próbki czerwonego spągowca przed i po eksperymencie

\begin{tabular}{|c|c|c|c|c|c|c|c|c|c|c|}
\hline $\begin{array}{c}\text { Kwarc } \\
{[\%]}\end{array}$ & $\begin{array}{c}\text { Plagioklazy } \\
{[\%]}\end{array}$ & $\begin{array}{c}\text { Skalen potasowy } \\
{[\%]}\end{array}$ & $\begin{array}{c}\text { Dolomit } \\
{[\%]}\end{array}$ & $\begin{array}{c}\text { Piryt } \\
{[\%]}\end{array}$ & $\begin{array}{c}\text { Anhydryt } \\
{[\%]}\end{array}$ & $\begin{array}{c}\text { Miki + illit } \\
{[\%]}\end{array}$ & $\begin{array}{c}\text { Chloryt } \\
{[\%]}\end{array}$ & $\begin{array}{c}\text { Suma } \\
{[\%]}\end{array}$ & $\begin{array}{c}\text { Suma minerałów ilastych } \\
{[\%]}\end{array}$ \\
\hline \multicolumn{7}{c|}{ Przed eksperymentem } \\
\hline 68,2 & 5,3 & 10,2 & 4,9 & 0,9 & 1,0 & 9,0 & 0,5 & 100,0 & 9,5 \\
\hline \multicolumn{8}{|c|}{ Po eksperymencie } \\
\hline 66,6 & 5,9 & 8,3 & 4,8 & 0,0 & 3,6 & 10,8 & 0,0 & 100,0 & 10,8 \\
\hline
\end{tabular}

Tablica 8. Wyniki mikrotomografii rentgenowskiej dla czerwonego spągowca

\begin{tabular}{|c|c|c|}
\hline \multicolumn{2}{|c|}{ Nr próbki CS2 - 19596 } \\
\hline \multirow{2}{*}{$\begin{array}{c}\text { Zmiana } \\
\text { porowatości }\end{array}$} & Przed & $0,3 \%$ \\
\hline \multirow{2}{*}{$\begin{array}{c}\text { Obrazy } \\
\text { struktury } \\
\text { porowej }\end{array}$} & $0,3 \%$ & \\
& & \\
\end{tabular}

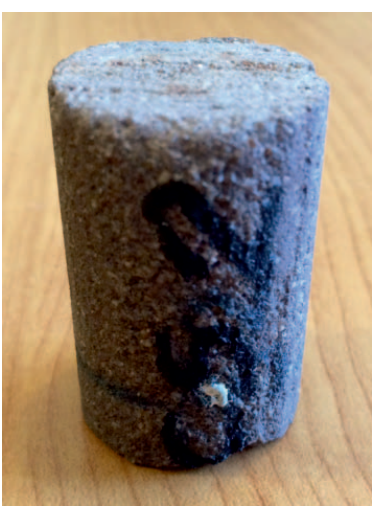

Rys. 8. Rdzeń czerwonego spągowca przygotowany do badań 


\section{Eksperyment 3}

Do wykonania eksperymentu nr 3 wykorzystano rdzeń oznaczony symbolem B75 (materiał skalny reprezentujący dolomit główny) o dobrych wartościach przepuszczalności i porowatości. Rdzeń nasycono analogicznie jak w poprzednich eksperymentach odpowiednio przygotowaną solanką pochodzącą z odwiertu Porażyn-2A.

W czasie 30-dniowego eksperymentu przez rdzeń przetłoczono $52 \mathrm{PV}$ (objętości porowej rdzenia) solanki
Na powyższych wykresach przedstawiono obraz struktury porowej sklasyfikowanej według objętości wydzielonych podsystemów porów. Kolorystyka odpowiada następującym zakresom objętości: kolor żółty $1 \div 9$ wokse-

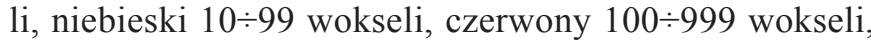
zielony 1000 $\div 9999$ wokseli, biały $10000 \div 99999$ wokseli, fioletowy 100 000 $\div 400000$ wokseli, różowy - powyżej 400000 wokseli. Rozmiar woksela dla badanej próbki wynosił $15 \times 15 \times 15 \mu \mathrm{m}^{3}$.

Tablica 9. Wyniki badań petrofizycznych próbki dolomitu głównego

\begin{tabular}{|l|c|c|c|c|c|}
\cline { 2 - 5 } \multicolumn{1}{c|}{} & $\begin{array}{c}\text { Współczynnik } \\
\text { przepuszczalności }\end{array}$ & $\begin{array}{c}\text { Współczynnik } \\
\text { porowatości efektywnej }\end{array}$ & $\begin{array}{c}\text { Objętość } \\
\text { przestrzeni porowej }\end{array}$ & $\begin{array}{c}\text { Gęstość } \\
\text { szkieletowa skał }\end{array}$ & $\begin{array}{c}\text { Masa } \\
\text { rdzenia }\end{array}$ \\
\cline { 2 - 6 }$\left[\begin{array}{c}{\left[\mathrm{g} / \mathrm{cm}^{3}\right]} \\
{[\mathrm{g}]}\end{array}\right.$ & 19,21 & 22,45 & 6,468 & 2,813 & 62,870 \\
\hline B75 przed eksperymentem & 19,96 & 22,16 & 6,377 & 2,793 & 62,570 \\
\hline B75 po eksperymencie & 0,75 & $-0,29$ & $-0,091$ & $-0,020$ & $-0,300$ \\
\hline B75 wartość zmian & 3,90 & 1,30 & 1,400 & 0,700 & 0,500 \\
\hline $\begin{array}{l}\text { B75 zmiana parametru } \\
\text { wyrażona w \% }\end{array}$ & & & & \\
\hline
\end{tabular}

nasyconej $\mathrm{CO}_{2}$, stale utrzymując ciśnienie 220 bar i temperaturę $100^{\circ} \mathrm{C}$. Wyniki badań próbki skalnej czerwonego spągowca przedstawiono w tablicach 9, 10 i 11 .

Próbka dolomitu głównego po przeprowadzonym badaniu składu nie wykazała znaczących zmian zawartości badanych minerałów (tablica 10). Zmniejszyła się ilość anhydrytu oraz halitu. W badanym rdzeniu nie wykazano w składzie minerałów ilastych. Zarejestrowane zmiany dla badanej próbki nie przekroczyły $1,1 \%$.
Tablica 10. Zmiany zawartości minerałów dla próbki dolomitu głównego przed i po eksperymencie

\begin{tabular}{|c|c|c|c|c|c|}
\hline $\begin{array}{c}\text { Kwarc } \\
{[\%]}\end{array}$ & $\begin{array}{c}\text { Dolomit } \\
{[\%]}\end{array}$ & $\begin{array}{c}\text { Anhydryt } \\
{[\%]}\end{array}$ & $\begin{array}{c}\text { Halit } \\
{[\%]}\end{array}$ & $\begin{array}{c}\text { SUMA } \\
{[\%]}\end{array}$ & $\begin{array}{l}\Sigma \text { il } \\
{[\%]}\end{array}$ \\
\hline \multicolumn{6}{|c|}{ Przed eksperymentem } \\
\hline 1,1 & 94,4 & 3,1 & 1,4 & 100,0 & 0,0 \\
\hline \multicolumn{6}{|c|}{ Po eksperymencie } \\
\hline 1,2 & 95,3 & 2,7 & 0,8 & 100,0 & 0,0 \\
\hline
\end{tabular}

Tablica 11. Wyniki mikrotomografii rentgenowskiej dla czerwonego spągowca

\begin{tabular}{|c|c|c|}
\hline \multicolumn{2}{|c|}{ Nr próbki B75 } \\
\hline \multirow{2}{*}{$\begin{array}{c}\text { Zmiana } \\
\text { porowatości }\end{array}$} & $1,0 \%$ & $1,3 \%$ \\
\hline & & Po \\
\hline $\begin{array}{c}\text { Obrazy } \\
\text { struktury } \\
\text { porowej }\end{array}$ & & \\
& & \\
& & \\
\end{tabular}

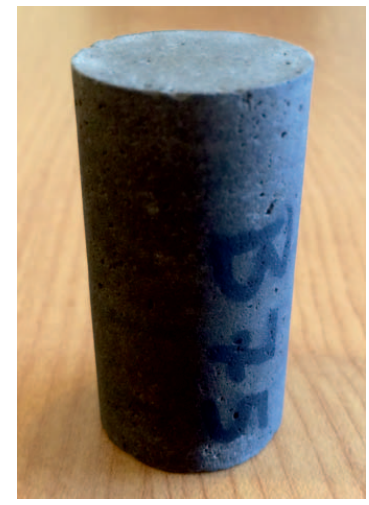

Rys. 11. Rdzeń dolomitu głównego przygotowany do badań

\section{Wnioski}

Do przeprowadzonych badań odziaływania gazów kwaśnych na skałę zbiornikową wykorzystano trzy próbki. Reprezentantem przedgórza Karpat był piaskowiec węglowiecki (próbka oznaczona numerem 2273). Druga próbka to dolomit główny - przedstawiciel największego złoża ropy naftowej w Polsce, trzecia - czerwony spągowiec jako reprezentant 
złoża solanki nasyconej metanem w niecce poznańskiej. Wyniki badań przepuszczalności i porowatości próbek skalnych (przed i po przeprowadzonym eksperymencie) wykazały dobre i bardzo dobre własności kolektorskie. W przypadku próbki piaskowca węglowieckiego współczynnik przepuszczalności zmniejszył się o 14,5\%, a porowatość zmalała o 2,5\%. Podobny efekt uzyskano dla próbki skalnej reprezentującej czerwony spągowiec, w przypadku którego zarejestrowano znaczący spadek (o 68\%) przepuszczalności, a także poprawę porowatości o 14\%. Zmniejszenie przepuszczalności dla obu próbek piaskowcowych najprawdopodobniej spowodowane było spęcznieniem iłów.

Przepuszczalność rdzenia dolomitu głównego uległa polepszeniu o 4\%, zaś porowatość nie zmieniła się. Fakt ten potwierdziły doniesienia z przemysłu dotyczące zatłaczania gazów kwaśnych do odwiertu B-28 na złożu Borzęcin, gdzie po około trzech miesiącach uzyskano polepszenie chłonności odwiertu, czego odzwierciedleniem był spadek ciśnienia zatłaczania.

Wyniki badań różnic w składzie mineralogicznym, przed i po przeprowadzonym eksperymencie oddziaływania $\mathrm{CO}_{2}$ na próbki skał zbiornikowych, należy interpretować $\mathrm{z}$ dużą ostrożnością. Badania pojedynczych rdzeni wiertniczych przy dużej zmienności w obrębie próbki mogą nie być reprezentatywne. Należy również pamiętać, że analizowany materiał skalny przed i po eksperymencie nie jest dokładnie taki sam, choć został wycięty z jednego fragmentu rdzenia. Powyższe rozważania potwierdzają badania z wykorzystaniem mikro- tomografii rentgenowskiej, które nie wykazały znaczącego wpływu eksperymentu na strukturę porową materiału skalnego. W przypadku piaskowca węglowieckiego (tablica 5) zauważono nieznaczny spadek porowatości (spadek o 1,1\%). Próbka czerwonego spągowca (tablica 8) nie uległa żadnym zmianom. Dla próbki dolomitu głównego (tablica 11) zaobserwowano niewielki wzrost porowatości (zmiana o zaledwie $0,3 \%$ ), co świadczy o nieznacznym oddziaływaniu $\mathrm{CO}_{2}$ (rozpuszczonego w solance) na badaną skałę.

Przebadane próbki nie wykazały znaczących różnic w składzie mineralogicznym, potwierdzając tym samym dobre własności magazynowe.

Wykonane eksperymenty pozwoliły na zbadanie wpływu rozpuszczonych gazów kwaśnych w solance na skałę zbiornikową. Były to pierwsze tego typu badania, w trakcie których cyklicznie przetłaczano przez rdzeń solankę z rozpuszczonym $\mathrm{CO}_{2}$. Na podstawie przeprowadzonych eksperymentów zbadane próbki (reprezentujące kolektory magazynowe) jednoznacznie można uznać za odpowiednie do podziemnego magazynowania $\mathrm{CO}_{2}$.

Na podstawie pomiarów przeprowadzonych w Zakładzie Geofizyki Wiertniczej INiG - PIB stwierdzono, że największy wpływ na wyniki ma rozrzut statystyczny wyników, który określono na poziomie $0,25 \%$ pomierzonej wielkości.

Badania skał metodą mikrotomografii rentgenowskiej oraz analizy składu mineralnego skał wykonano w Zakładzie Geofizyki Wiertniczej INiG - PIB.

\section{Prosimy cytować jako: Nafta-Gaz 2016, nr 7, s. 520-527, DOI: 10.18668/NG.2016.07.04}

Artykuł nadesłano do Redakcji 1.12.2015 r. Zatwierdzono do druku 7.04.2016 r.

Artykuł powstał na podstawie pracy statutowej pt.: Badania laboratoryjne oddziaływania gazów kwaśnych na skałę zbiornikowa w procesach sekwestracji $\mathrm{CO}_{2}$ - praca INiG - PIB na zlecenie MNiSW; nr zlecenia: 25/KB/15, nr archiwalny: DK-4100-25/15.

\section{Literatura}

[1] Credos A., Bildstein O., Julien M., Rayn J., Petronin J. C., Lilo M., Pozo C., Geniaut G.: Experimental and modeling study of geochemical reactivity between clayey caproks and $\mathrm{CO}_{2}$ I geological storage conditions. Energy Procedia 2009, s. 3445-3452.

[2] Gunter W. D., Wiwchar B.: Perkins Aquifer disposal of $\mathrm{CO}_{2}$-rich greenhouse gases: extension of the time scale of experiment for $\mathrm{CO}_{2}$-sequestering reactions by geochemical modeling. Mineral. Petrol. 1997, vol. 59, s. 121-140.

[3] Kampman N. J.: Fluid-Rock Interactions in a Carbon Storage Site Analogue, Green River, Utah. A thesis submitted for the degree of Doctor of Philosophy 2010.

[4] Lubaś J.: Pionierskie doświadczenia Polski w zakresie sekwestracji dwutlenku węgla. Przegląd Geologiczny 2007, nr 8, s. 663-665.

[5] Lubaś J.: Pierwsza europejska przemystowa instalacja sekwestracji $\mathrm{CO}_{2}$. Nafta-Gaz 2008, nr 1, s. 49-51.

[6] Lubaś J., Szott W., Jakubowicz P.: Effects of acid reinjection on $\mathrm{CO}_{2}$ concentration in natural gas produced from Borzęcin reservoir. Nafta-Gaz 2012, nr 7, s. 405-410.

[7] Ortoleva P. J., Dove P., Richter F.: Geochemical perspectives on $\mathrm{CO}_{2}$ sequestration, Manuscript prepared for US Department of Energy Workshop on "Terrestrial Sequestration of $\mathrm{CO}_{2}-$ An Assessment of Research Needs". Gaithersburg, Maryland, 1998.

[8] Tarkowski R., Menecki M.: Badania oddziaływania $\mathrm{CO}_{2}$ na mezozoiczne skały zbiornikowe w celu określenia ich przydatności do geologicznej sekwestracji dwutlenku węgla. Instytut Gospodarki Surowcami mineralnymi i Energią PAN. Kraków 2009.

[9] Warnecki M.: Rozpuszczalność $\mathrm{CO}_{2}$ i rodzimym gazów ziemnych w solance złożowej. Nafta-Gaz 2010, nr 1, s. 19-26.

[10] Xu T., Apps A., Pruess K.: Numerical simulation of $\mathrm{CO}_{2}$ disposal by mineral traping in deep aquifers. Applied Geochemistry 2004, nr 19, s. 917-936.

[11] Zemke K., Kummerow J., Wandrey M.: Petrophisical laboratory investigations of carbon dioxide storage in subsurface saline aquifer in Ketzin/Germany within the scope of $\mathrm{CO}_{2}$ Sink. International Journal of Greenhouse Gas Control 2010, s. 990-999.

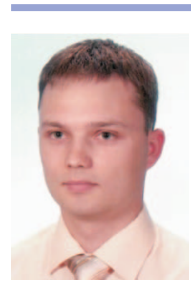

Mgr inż. Sławomir SZUFLITA

Asystent w Zakładzie Badania Złóż Ropy i Gazu. Instytut Nafty i Gazu - Państwowy Instytut Badawczy ul. Lubicz 25 A

31-503 Kraków

E-mail: szuflita@inig.pl 